\title{
Adsorption of Xylene From Air by Natural Iranian Zeolite
}

\author{
Zohreh Vahdat Parast ${ }^{1}$; Hassan Asilian ${ }^{2, *}$; Ahmad Jonidi Jafari ${ }^{3}$ \\ ${ }^{1}$ Department of Environmental Health, Faculty of Medical Sciences, Tarbiat Modares University, Tehran, IR Iran \\ 2Department of Environmental Health, Faculty of Medical Sciences, Tarbiat Modares University, Tehran, IR Iran \\ 3 Department of Occupational Health, Faculty of Medical Sciences, Tarbiat Modares University, Tehr
${ }^{2}$ Department of Environmental Health, Faculty of Medical Sciences, Iran University, Tehran, IR Iran \\ ${ }^{*}$ Corresponding author: Hassan Asilian, Department of Occupational Health, Faculty of Medical Sciences, Tarbiat Modares University, Tehran, IR Iran. Tel: +98-2182883564, E-mail: \\ asilia_h@modares.ac.ir \\ Received: January 13, 2014; Revised: February 24, 2014; Accepted: March 3, 2014
}

\begin{abstract}
Background: Aromatic organic solvents are extensively used in various industries. Xylene is a colorless, transparent liquid, with the characteristic odor of the aromatic hydrocarbons family, which is widely used in industries. Adsorption is a conventional method of purifying polluted air containing volatile organic compounds(VOCs).Zeolite has many unique properties such as high capacity, molecular sieve characteristics, nonflammability, thermal stability, and strong acid sites. Moreover, it is reconstructed at low temperatures.

Objectives: In this study, we investigated the effect of various parameters on the adsorption capacity of natural zeolite (clinoptilolite) for xylene adsorption.

Materials and Methods: Physical and chemical properties of natural zeolites were tested by scanning electron microscopy (SEM) and energy dispersive spectroscopy (EDS) and elemental analyses of natural zeolites were characterized by X-ray diffraction. Xylene concentration was measured at various times through concentrations-measured valve before and after the adsorbent bed reactor by the direct reading of Phocheck (Ion Science Ltd, UK).

Results: Experimental results showed that clinoptilolite is a potential sorbent for xylene in the range of ppm, and the breakthrough time would be reduced by increasing the concentration. The optimal temperature of xylene adsorption on natural zeolite was $35^{\circ} \mathrm{C}$ and by increasing the temperature, the absorption efficiency of clinoptilolite was declined. The results showed that the breakthrough time and the exhaustion point time at the optimal conditions are 65 and 95 minutes, respectively. Adsorption capacity of clinoptilolite was obtained as $1.69 \mathrm{mg}$ xylene/g zeolite.

Conclusions: Experimental results showed that clinoptilolite is a potential sorbent for xylene in the range of ppm and the breakthrough time was reduced by increasing the concentration. Adsorption rate were increased by increasing concentration of xylene. Presence of xylene molecules in high concentration enhances their transfer and contact with adsorbent; as a result, by increasing gas concentration, breakthrough time in zeolite will be shorter.
\end{abstract}

Keywords: Zeolites; Xylenes; Adsorption

\section{Background}

Volatile organic compounds (VOCs) are air pollutant factors that are emitted from volatile liquids or solids. These compounds contain organic carbon products and are vaporized by a various process (1). Eye and throat irritation as well as damage to central nervous and liver may occur due to the prolonged exposure to VOCs. VOCs may also have carcinogenic effects. The role of VOCs as a precursor in the formation of photochemical smog, global warming, climate change, and the other environmental problems is fully established $(2,3)$.

Xylene is one of the most commonly used aromatic solvents in industry. Xylenes exist in ambient air as a mixture of ortho-isomers, meta-isomers, and para-isomers. At room temperature, xylene isomers are colorless, volatile, and flammable liquids with a sweet odor (4-6). It is often combined with other aromatic and aliphatic hydrocarbons.

Xylene was used in 110 companies and was the second most frequent organic solvent detected in the ambient air (6). Xylene is very harmful to both human health and the environment, even at very low concentrations (7). Sources of xylenes include petrol, motor vehicles, petroleum refineries and terminals, service stations, lawnmowers and other petrol-fuelled implements, chemical, polyester, and paint manufacture, dyes, and lacquers, wood burning stoves, and fireplaces (6). According to studies, xylene concentration of more than 270 to 350 ppm has been reported in the industry (8). The current occupational safety and health act (OSHA) standard for xylene is an average of 100 ppm over an eight-hour work shift. National Institute of Occupational Safety and Health (NIOSH) has recommended to change the permissible exposure limit to an average of 100 ppm over a work shift of up to ten hours per day, forty hours per week, with an acceptable average ceiling level of 200 ppm over tenminutes period (9). 
VOCs are solved into the blood and are distributed throughout the body. Distribution of absorbed xylene in humans and rodents is characterized by preferential uptake in well-perfused and lipophilic tissues such as brain, liver, lungs, and body fat. Studies in humans and animals show that the central nervous system is one of the main target of xylenes (10). According to the aforementioned information, for preventing health and environmental problems, xylene should be removed from polluted air stream before emission to the environment (4). VOCs are present in many waste gases and can be effectively removed through the adsorption process. Activated carbon and zeolite are common adsorbent (7). Adsorption is accomplished by two types of chemical and physical methods, but the maximum amount of adsorption is via physical type (11).

Due to some advantages such as capability of zeolites to adsorb molecules in high moisture, resistance to heating, complete regeneration, and huge resource, they are more cost-effective than activated carbon in certain systems. Moreover, zeolite systems can be one of the effective solutions to remove xylene due to the simplicity of operation and easy maintenance (12).

In order to optimize design of adsorption processes, it was necessary to have an accurate modeling to simulate the dynamic behavior of the adsorption system. A requisite for the proper design of the adsorption processes is prediction of the concentration-time profiles, or the breakthrough curve of the column output (13). The purpose of this study was to evaluate the breakthrough curves of zeolite for xylene adsorption; therefore, we tested the effect of xylene concentration, flow rate, temperature, and other related parameters. In this study, xylene was used because of its frequent use as a solvent in industries (14) and natural zeolite was used as sorbent. There are huge resources of zeolite especially clinoptilolite in Iran for example in Semnan, Miyaneh, Talheh, Roodehen, Taleghan, Tabas, Kerman and Zahedan (15).

\section{Objectives}

In this study, we investigated the effect of various parameters on the adsorption capacity of natural zeolite (clinoptilolite) for xylene adsorption.

\section{Materials and Methods}

Zeolite was purchased from Afrand Tooska Company. In order to prepare the adsorbent, zeolite was first grind and then separated in three sizes by means of graded sieving (standard ASTM sieves) (12). Characteristics of prepared zeolite as well as its elements were analyzed by scanning electron microscopy (SEM), energy dispersive spectroscopy (EDS), X-ray diffraction (XRD), and X-ray fluorescence (XRF).

Xylene vapor was prepared through vapor saturation method $(16,17)$. Porosity was determined by measuring the amount of water required to saturate a given volume of zeolite in a graduated cylinder, which was similar to the reactor system (18). The water content of zeolite was measured through heat treatment in a furnace of $300^{\circ} \mathrm{C}$ for 24 hours (by means of weight difference before and after heating).

To perform the test, $10 \mathrm{~g}$ of zeolite sample was weighed by an accurate electronic microbalance. That was conditioned for one hour at $300^{\circ} \mathrm{C}$ in an electric furnace; these conditions can eliminate over $98 \%$ of water in the zeolite (7). Then the zeolite sample was placed in the adsorbent bed reactor. According to studies, a steel tube was prepared with 2.2-cm internal diameter and $15-\mathrm{cm}$ height as adsorbent bed reactor (19). The total schematic of system is shown in Figure 1.

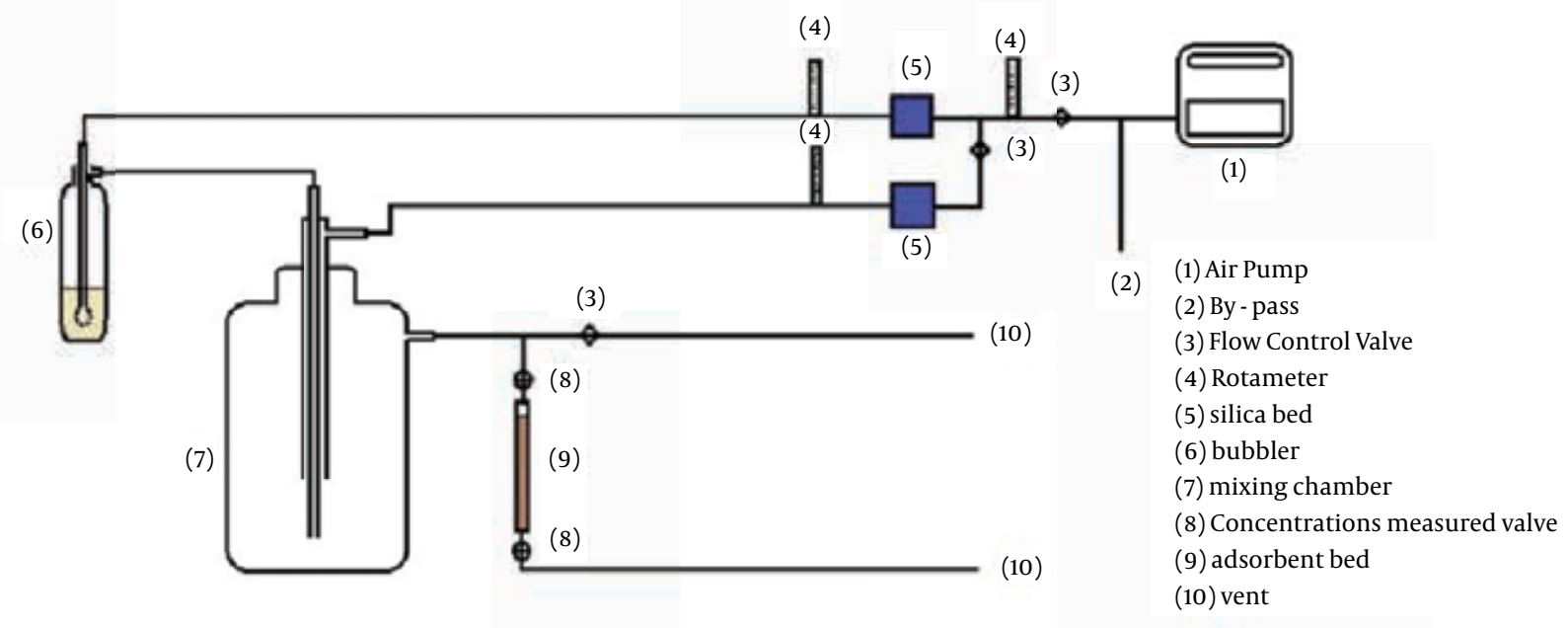

Figure 1. System Schematic 
Before and after placing xylene in adsorbent bed, its concentration was measured by Phocheck (Tiger model, Ion Science Ltd, UK) at different time points. Each experiment was performed three times and breakthrough and saturated point for each of them was recorded. To regulate and maintain a constant temperature, we used a heater tape and digital thermostat (Pooyesh, TMC 101) that was placed around the adsorbent bed reactor and was controlled by thermocouple sensor.

The breakthrough time was defined as the time taken to make the outlet concentration reach $5 \%$ of inlet concentration $(2,7,20,21)$. Typically, when the outlet concentration is equal to the inlet concentration, the absorption ends that means that equilibrium is achieved (saturated zeolite by xylene at the selected temperature) (14).

\section{Results}

\subsection{Adsorbent Characteristics}

Adsorbent characteristics were achieved by XRD and XRF analyses. Figure 2 shows the XRD profiles natural zeolite, evaluation of main images in XRD analysis indicated that this profiles was in agreement with standard card 80-0464, which is from clinoptilolite family.

Table 2 shows XRF analysis result for zeolite samples in which the ratio of $\mathrm{Si} / \mathrm{Al}$ is equivalent to 6.47 . The results show that the porosity of this type of zeolite was $24 \%$ and the quantity of water in the zeolite samples were calculated at $7.73 \%$. Different experimental conditions in this study are shown in Table 1.

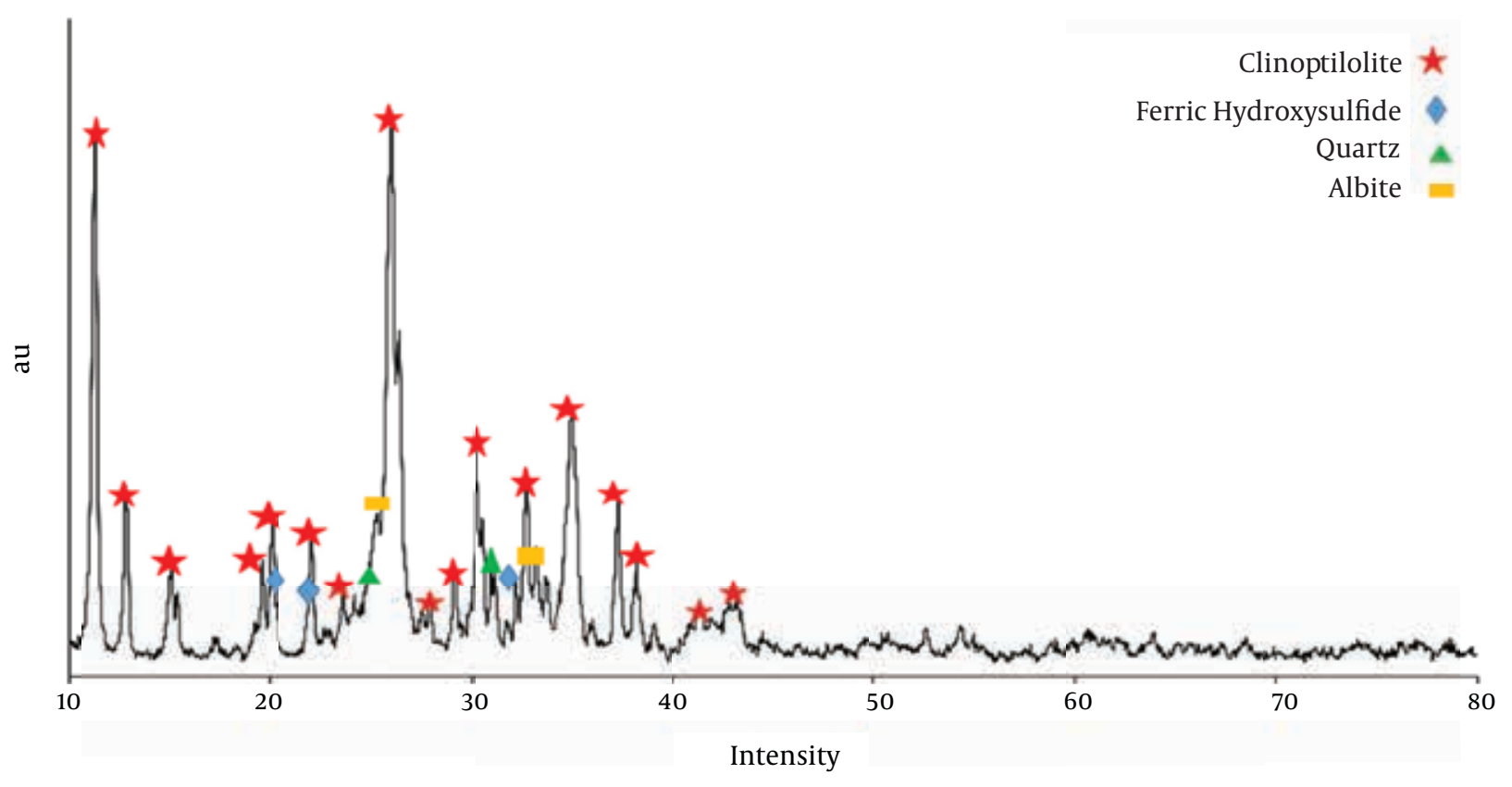

Figure 2. Analysis of X-Ray Diffraction results of Iranian Natural Zeolite Samples

Table 1. Different Experimental Conditions

\begin{tabular}{lc}
\hline Test Cases & Test Values \\
\hline Inlet Xylene Concentration, ppm & $100,200,300$ \\
\hline Inlet Gas Flow, $\mathbf{L} / \mathbf{m i n}$ & $0.3,0.4,0.5$ \\
\hline Bed Temperature, ${ }^{\circ} \mathbf{C}$ & $35,40,50,75,100$ \\
The Amount of Adsorbent, $\mathbf{g}$ & 5,10 \\
\hline Adsorbent Particle Size, $\mathbf{m m}$ & $0.5,1,1.5$ \\
\hline
\end{tabular}

Table 2. Analysis of X-Ray Fluorescent Results of Iranian Natural Zeolite Samples a

\begin{tabular}{cccccccccccccc}
\hline Natural Zeolite, \% & L.O.I. & $\mathrm{Na}_{2} \mathbf{O}$ & $\mathbf{M g O}$ & $\mathrm{Al}_{2} \mathbf{O}_{3}$ & $\mathbf{S i O}_{2}$ & $\mathbf{P}_{2} \mathbf{O}_{5}$ & $\mathbf{S O}_{3}$ & $\mathbf{K}_{2} \mathbf{O}$ & $\mathbf{C a O}$ & $\mathrm{TiO}_{2}$ & $\mathrm{Fe}_{2} \mathbf{O}_{3}$ & $\mathbf{S r}$ & $\mathbf{Z r}$ \\
\hline & 12.87 & 3.094 & 0.757 & 10.648 & 68.847 & 0.03 & 0.024 & 1.309 & 1.316 & 0.163 & 0.881 & 0.043 & 0.018 \\
\hline
\end{tabular}

\footnotetext{
a Abbreviation: Sr, strontium.
} 
Vahdat Parast Z et al.

\begin{tabular}{|c|c|c|c|c|c|c|c|c|c|}
\hline \multirow{2}{*}{$\begin{array}{l}\text { Optimal } \\
\text { Parameters }\end{array}$} & \multicolumn{3}{|c|}{ Test Conditions } & \multirow[t]{2}{*}{$t_{B}$, min } & \multirow[t]{2}{*}{$\mathbf{t}_{\mathrm{E}}, \min$} & \multirow[t]{2}{*}{$\mathbf{V}_{\mathrm{B}}, \mathrm{L}$} & \multirow[t]{2}{*}{$\mathbf{V}_{\mathrm{E}}, \mathbf{L}$} & \multirow{2}{*}{ 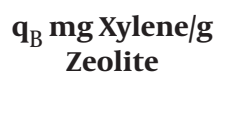 } & \multirow{2}{*}{ 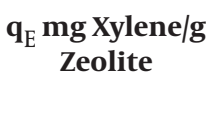 } \\
\hline & $\mathrm{Q}, \mathrm{L} / \mathrm{min}$ & C, ppm & $\mathrm{C}, \mathrm{mg}$ & & & & & & \\
\hline $\begin{array}{l}\text { Tempera- } \\
\text { ture, } 35^{\circ} \mathrm{C}\end{array}$ & 0.3 & 200 & 0.868 & 51 & 100 & 15.3 & 30 & 1.33 & 2.604 \\
\hline $\begin{array}{l}\text { Concentra- } \\
\text { tion, } 200 \\
\text { ppm }\end{array}$ & 0.3 & 100 & 0.434 & 90 & 160 & 27 & 48 & 1.17 & 2.08 \\
\hline $\begin{array}{l}\text { Flow rate, } \\
0.3 \mathrm{~L} / \mathrm{min}\end{array}$ & 0.3 & 200 & 0.868 & 51 & 100 & 15.3 & 30 & 1.33 & 2.604 \\
\hline $\begin{array}{l}\text { Particle } \\
\text { size, } 0.5 \\
\text { mm }\end{array}$ & 0.3 & 200 & 0.868 & 65 & 95 & 19.5 & 28.5 & 1.69 & 2.47 \\
\hline $\begin{array}{l}\text { Weight of } \\
\text { the adsor- } \\
\text { bent bed, } \\
10 \mathrm{~g}\end{array}$ & 0.3 & 200 & 0.868 & 51 & 100 & 15.3 & 30 & 1.33 & 2.604 \\
\hline
\end{tabular}

${ }^{a}$ Abbreviations: $\mathrm{V}_{\mathrm{B}}$, volume of breakthrough point; $\mathrm{v}_{\mathrm{E}}$, volume of exhaustion point; $\mathrm{t}_{\mathrm{B}}$, time of breakthrough point; $\mathrm{t}_{\mathrm{E}}$, time of exhaustion point; $\mathrm{q}_{\mathrm{B}}$, breakthrough capacity; and $\mathrm{q}_{\mathrm{E}}$, exhaustion capacity.

Figure 3. Effects of Temperature on the Breakthrough Point Curve of Xylene on Iranian Natural Zeolite
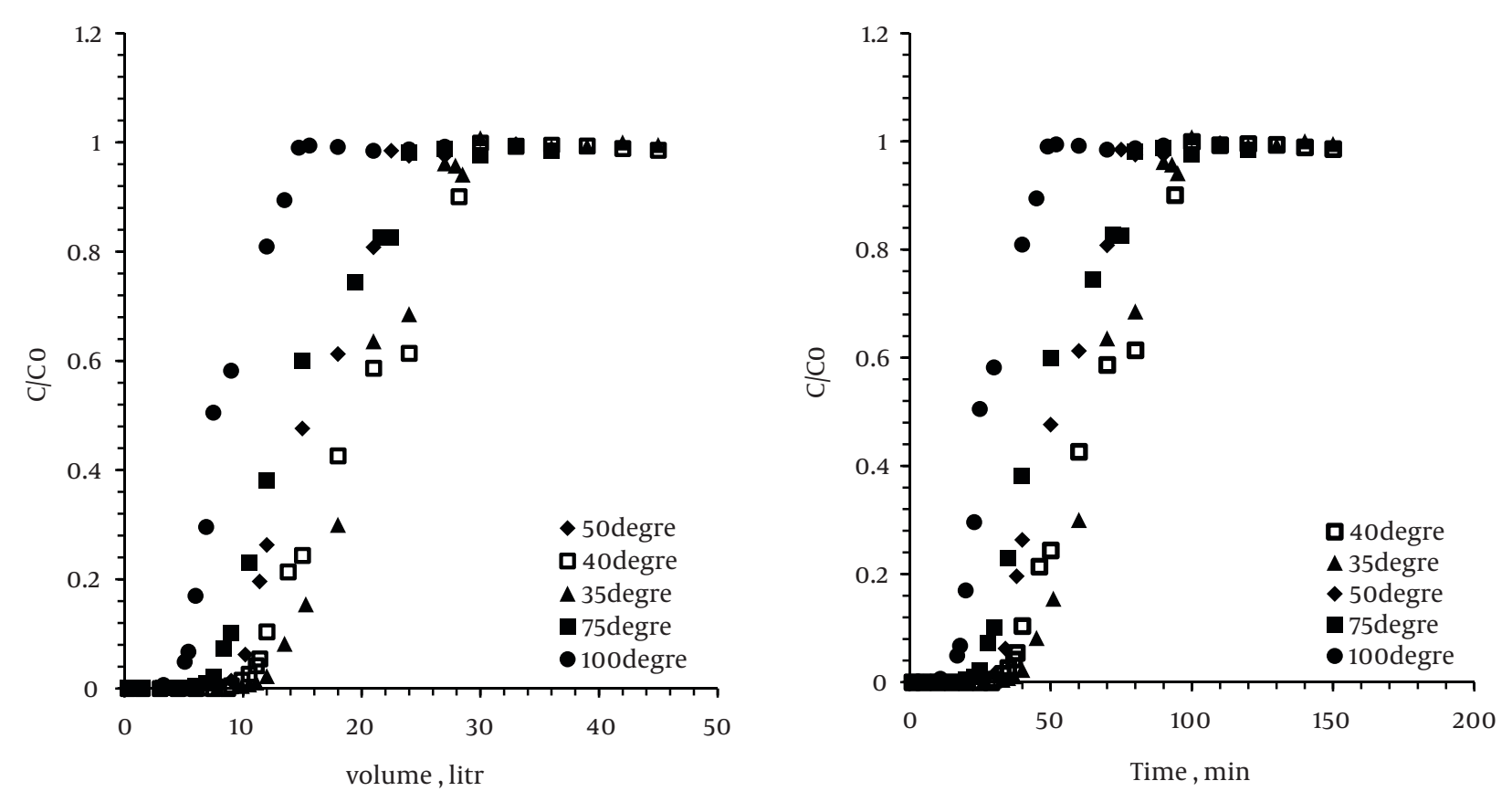

$\mathrm{w}=10 \mathrm{~g}, \mathrm{Q}=0.3 \mathrm{~L} / \mathrm{min}, \mathrm{mesh}=1 \mathrm{~mm}$, and inlet concentration (Cinlet) $=200 \mathrm{ppm}$.

\subsection{The Effect of Temperature}

To determine the effect of temperature on xylene adsorption, experiments were performed at different temperatures (35\%, 40\%, 50\%, 75\%, and 100\%). In all experiments the inlet xylene concentration was fixed at 200 ppm, weight of zeolite sample and the gas flow rate were $10 \mathrm{~g}$ and $0.3 \mathrm{~L} / \mathrm{min}$, respectively. Figure 3 shows the breakthrough curves during adsorption by the zeolites at five different temperatures.

As can be observed in the diagram, the breakthrough 
point duration at $35^{\circ} \mathrm{C}$ and $40^{\circ} \mathrm{C}$ were 51 and 40 minutes, respectively. On the other hand, the total adsorption and the exhaustion point duration were the same for both of them (100 minutes). Therefore, increasing the temperature will reduce time and volume of the breakthrough point and exhaustion point at zeolite bed.

When bed temperature was increased to $100^{\circ} \mathrm{C}$, the breakthrough curve was shifted further, which indicates the quick saturated bed. Therefore, at the temperature of $100^{\circ} \mathrm{C}$, breakthrough and exhaustion time were respectively 20 and 52 minutes. Thus, the results indicated that the optimum temperature for taking out xylene from air by zeolites was $35^{\circ} \mathrm{C}$.

\subsection{The Effect of Xylene Concentration}

To determine the effect of the xylene concentration at breakthrough point, tests were performed for different inlet concentrations of xylene, i.e.100, 200, and 300 ppm. For each run, $10 \mathrm{~g}$ of zeolite was set in bed with an optimum temperature $\left(35^{\circ} \mathrm{C}\right)$ and the flow rate of $0.3 \mathrm{~L} / \mathrm{min}$. As Figure 4 shows, with increase in concentrations, the breakthrough time was decreased. Therefore, with an increase in concentration from 100 to 300 ppm, the breakthrough time decreased from 90 to 35 minutes. However, with an increase in concentration, the exhaustion time was reduced from 160 to 92 minutes.

The results showed that decreasing inlet concentration led to an increase in time and volume of the breakthrough and exhaustion point. By a decrease in the inlet concentration at a certain flow rate, the total amount of VOC imported into larger pores of the zeolite was decreased. Thus, for saturation of the zeolite bed is required a relatively long time.

\subsection{The Effect of Air Flow}

Experiments were conducted at various flows: 0.3, 0.4, and $0.5 \mathrm{~L} / \mathrm{min}$. In all the test runs, the weight of the zeolite was $10 \mathrm{~g}$, the temperature of the bed was $35^{\circ} \mathrm{C}$, and inlet concentration of stream was kept constant at 200 ppm.

Figure 5 shows the breakthrough point curve of VOC. As can be seen, when the flow rate increased from 0.3 to 0.5 $\mathrm{L} / \mathrm{min}$, the breakthrough time and exhaustion point duration were reduced from 43 to 30 minutes and 100 to 50 minutes, respectively.

By increasing the flow rate, breakthrough time of zeolite was reduced. On the other hand, by increasing the flow rate at a certain VOC concentration, the input VOC flow into the zeolite pores per time unit was increased and thus, did not have sufficient time for adsorption.

\subsection{The Effect of Particle Size}

In this study, three size of zeolite particle, in other words, 0.5, 1, and $1.5 \mathrm{~mm}$, were tested. For each run, $10 \mathrm{~g}$ of the zeolite sample was used. The bed temperature was set at the predetermined optimum temperature $\left(35^{\circ} \mathrm{C}\right)$ and the flow rate was set at $0.3 \mathrm{~L} / \mathrm{min}$.

As observed in Figure 5, by decreasing the particle size of the zeolite, the time and volume of the breakthrough and exhaustion points were increased.

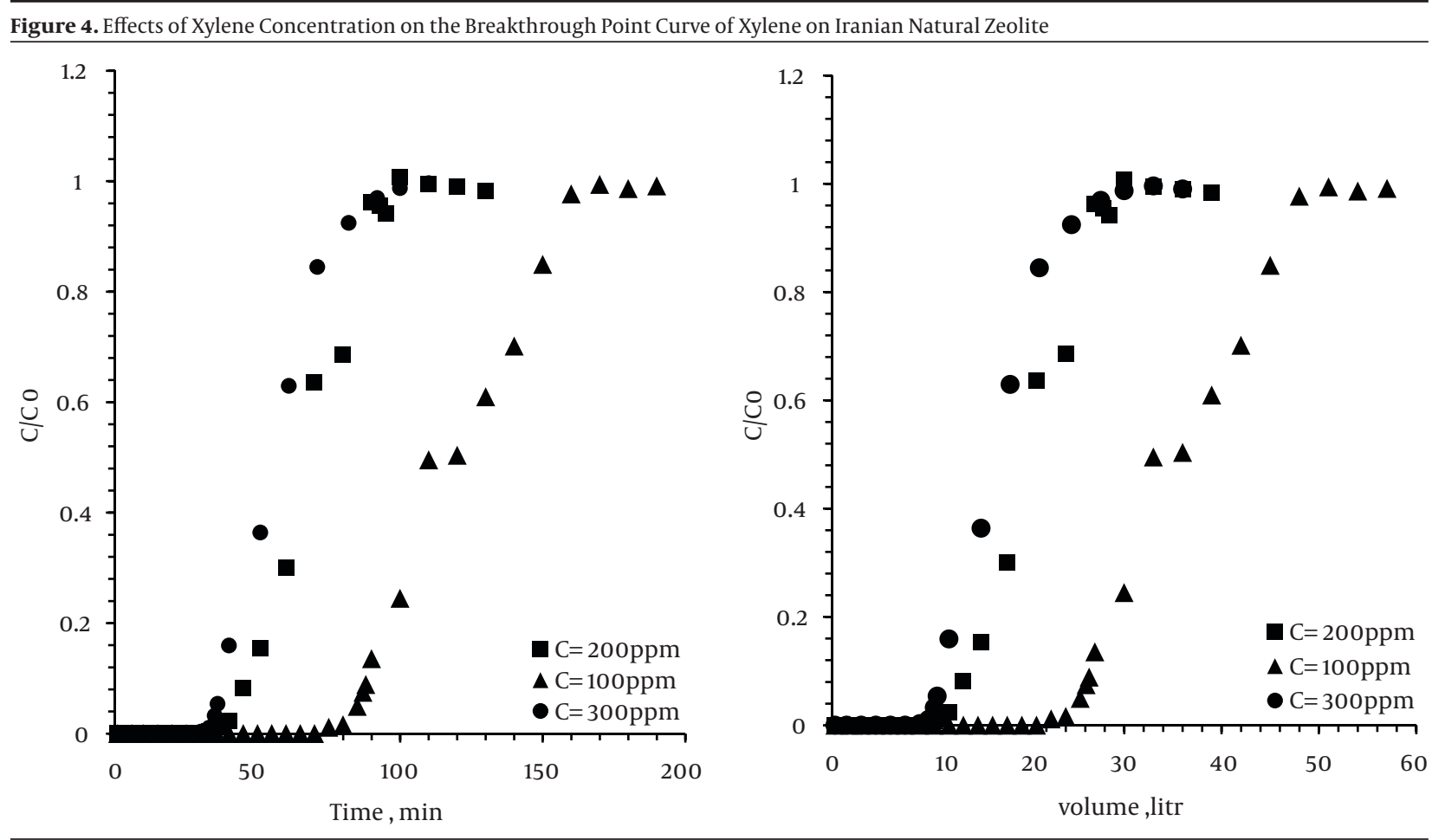

$\mathrm{w}=10 \mathrm{~g}, \mathrm{Q}=0.3 \mathrm{~L} / \mathrm{min}$, mesh $=1 \mathrm{~mm}$, and $\mathrm{T}=35^{\circ} \mathrm{C}$. 


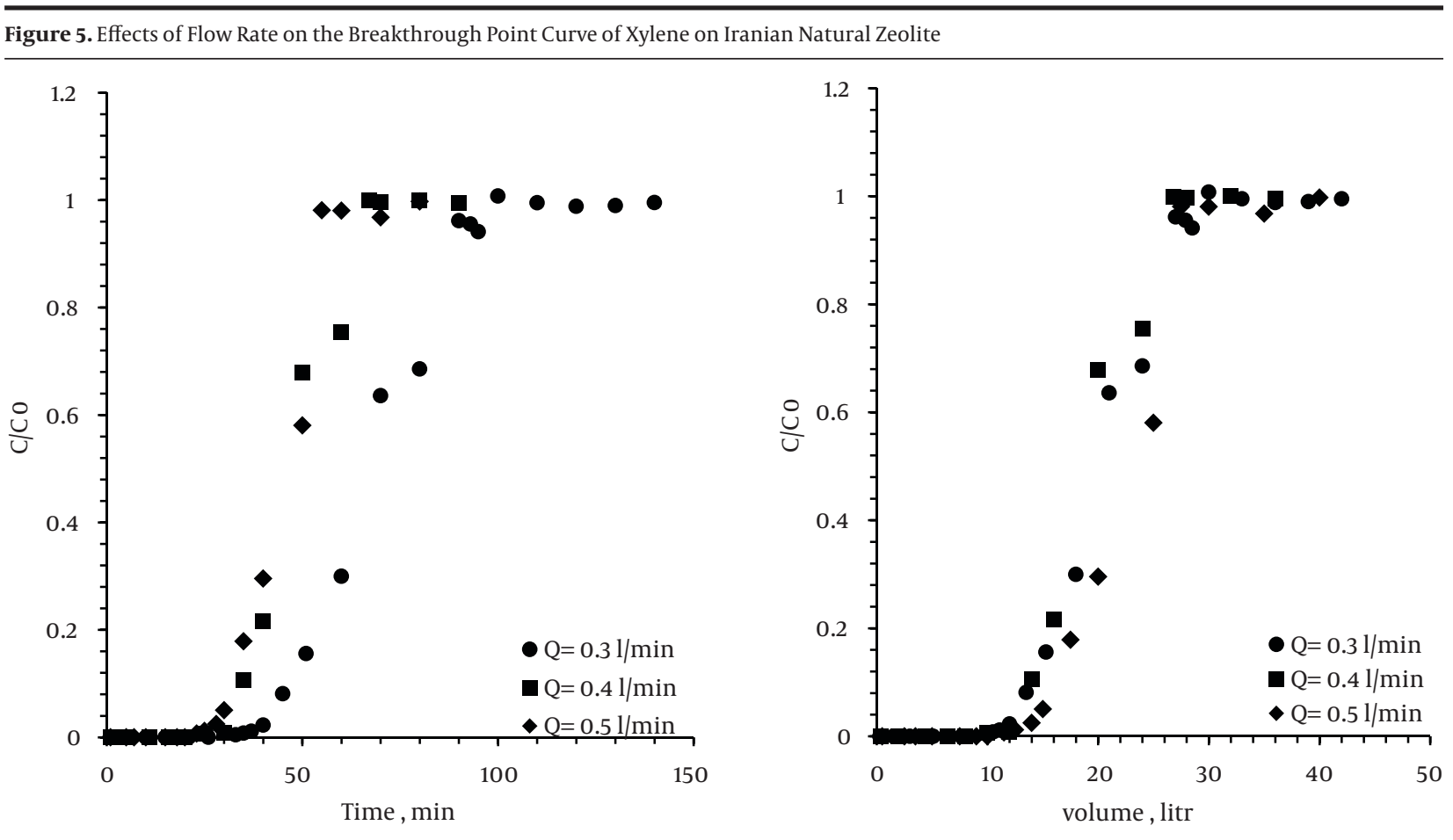

$\mathrm{w}=10 \mathrm{~g}, \mathrm{C}=200 \mathrm{ppm}$, mesh $=1 \mathrm{~mm}$, and $\mathrm{T}=35^{\circ} \mathrm{C}$.

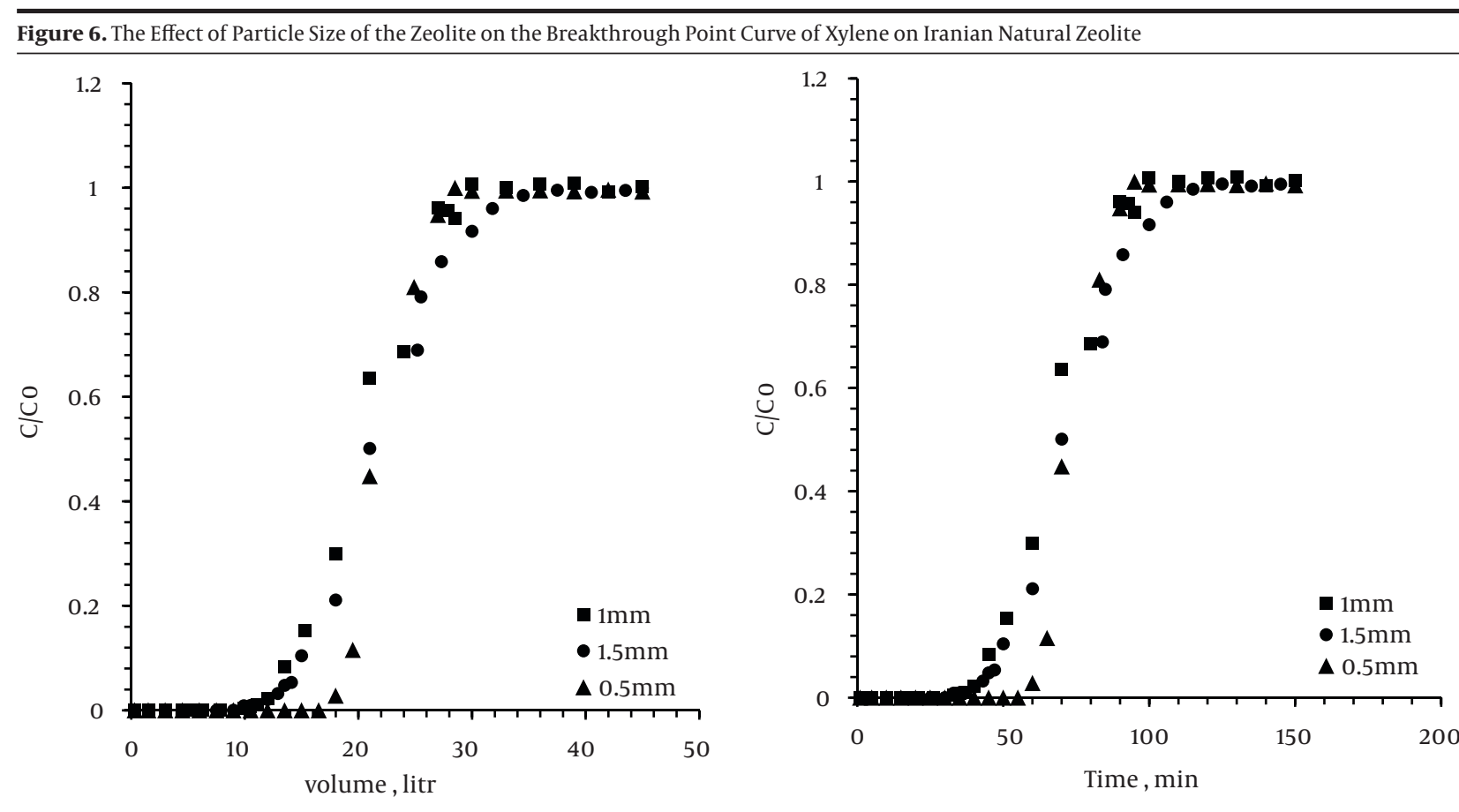

$\mathrm{W}=10 \mathrm{~g}, \mathrm{Q}=0.3 \mathrm{~L} / \mathrm{min}, \mathrm{T}=35^{\circ} \mathrm{C}$, inlet concentration $($ Cinlet $)=200 \mathrm{ppm}$.

\subsection{The Effect of Zeolite Weight}

The experiments were performed on different zeolite weights ( 5 and $10 \mathrm{~g}$ ) in the absence of the other variables. As we expected and saw in the results of the volume and duration of the breakthrough and exhaustion points, by increasing the amount of adsorbent, the level of active sites for the absorbed VOC was increased. 


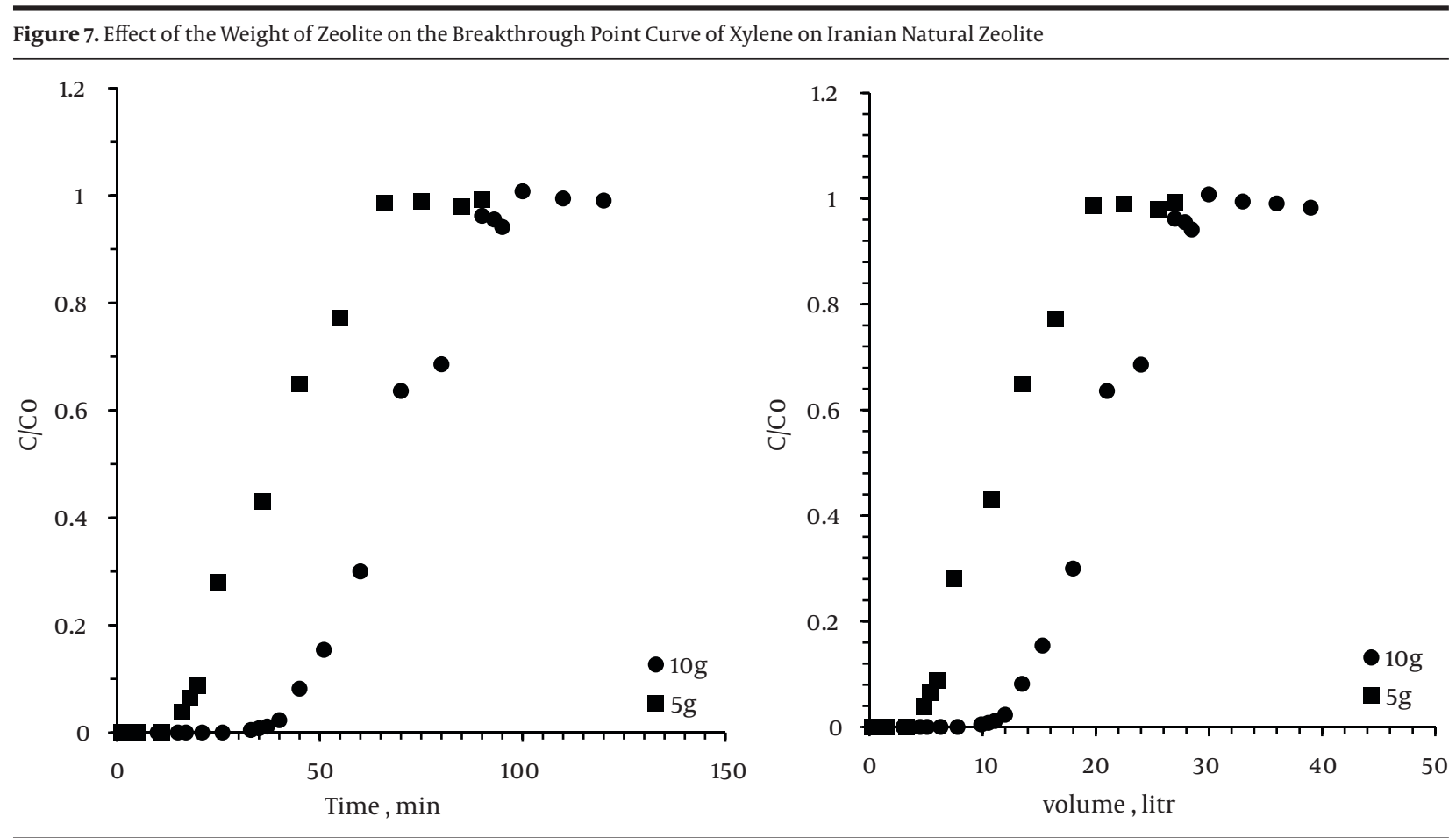

Mesh: $1 \mathrm{~mm}, \mathrm{Q}=0.3 \mathrm{~L} / \mathrm{min}, \mathrm{T}=35^{\circ} \mathrm{C}$, and inlet concentration (Cinlet) $=200 \mathrm{ppm}$.

\section{Discussion}

A number of operational conditions influenced the rate of xylene uptake by natural zeolite. These include flow rate, particle size, zeolite weight, temperature, and xylene concentration.

\subsection{The Effect of Temperature}

The optimum temperature of xylene adsorption on natural zeolite was $35^{\circ} \mathrm{C}$ and by increasing temperature, the adsorption efficiency of natural zeolites was declined. It is important to note that the observed reverse trend in the breakthrough characteristic at higher temperatures was typical to most of the adsorbents/adsorbate system. This reduced adsorption due to loss of the active sites for adsorption at high temperatures (2). Since the adsorption is an exothermic process, adsorption rate is inversely proportional to temperature. On the other hand, by increasing temperature, adsorption rate is reduce and rising temperatures, makes the desorption to the system.

\subsection{The effect of Xylene Concentration}

An increase in initial xylene concentration resulted in an increase in the amount of adsorbed xylene and a decrease in total efficiency of natural zeolite for the removal of xylene from air. This decrease in efficiency was seen by a general reduction in the adsorption percentage, which represents the efficiency of the process. Adsorption rate was increased by increasing concentration of xylene. The presence of abundant xylene molecules enhances trans- fer and contact with adsorbent; as a result, by increasing gas concentration, breakthrough time will be shorter in zeolite.

\subsection{The Effect of Air Flow}

These investigations also showed that, in the same conditions, an increase in the gas flow rate caused a decrease in the breakthrough and saturation time. Slower flow rates gave better adsorption efficiencies and capacities in comparison with faster ones. Increasing the flow rate, produces the turbulent flow and xylene molecules would not have enough time for adsorption at the zeolite.

\subsection{The Effect of Particle Size and Zeolite Weight}

More amount of adsorbent resulted in greater adsorption efficiencies due to an increase in residence time and available adsorption sites. In addition, by increasing the sorbent particle size from 0.5 to $1.5 \mathrm{~mm}$, the adsorption capacity and breakthrough time were considerably decreased although a decrease in the particle size caused an increase in the system pressure drop.

These findings are of particular importance in designing selective adsorbents for environmental applications such as the removal of VOCs and xylene in industries. Experimental results showed that Iranian natural zeolite is potentially a sorbent for xylene in the examined range of ppm concentration, especially at lower flow rates. This study showed good agreement with other studies (22-24). To optimize the conditions of the adsorption process, fur- 
ther studies should be performed for other gases in VOC groups.

\section{Acknowledgements}

The authors are grateful to Dr. Yamini, Chemistry Department of Tarbiat Modares University, who advised on chemical problems, and Eng Solaimanian for his professional help in the laboratory.

\section{Authors' Contributions}

Study concept and design: Zohreh Vahdat Parast, Hassan Asilian, and Ahmad Jonidi Jafari. Acquisition of data: Zohreh Vahdat Parast. Data analysis and interpretation: Zohreh Vahdat Parast, Hassan Asilian, and Ahmad Jonidi Jafari. Drafting of the manuscript: Zohreh Vahdat Parast. Critical revision of the manuscript for important intellectual content: Hassan Asilian and Ahmad Jonidi Jafari. Statistical analysis, administrative, technical, and material support, and study supervision: Hassan Asilian.

\section{Financial/Support}

This study was supported by grant from Tarbiat Modares University, Tehran, Iran.

\section{References}

1. Noordally E, Richmond JR, Tahir SF. Destruction of volatile organic compounds by catalytic oxidation. Catal Today. 1993;17(1):35966.

2. Das D, Gaur V, Verma N. Removal of volatile organic compound by activated carbon fiber. Carbon. 2004;42(14):2949-62.

3. Silva B, Figueiredo H, Santos VP, Pereira MF, Figueiredo JL, Lewandowska $\mathrm{AE}$, et al. Reutilization of $\mathrm{Cr}-\mathrm{Y}$ zeolite obtained by biosorption in the catalytic oxidation of volatile organic compounds. J Hazard Mater. 2011;192(2):545-53.

4. Wong CT. . Removal Of Volatile Organic Compound (Voc) From Air Using Zeolite Based Adsorption-Catalytic Combustion System [TD885.

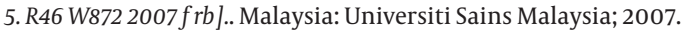

5. Identity C, Properties C. Chemical and Physical Information.California: Fishbein; 1985.

6. Bonde JP. Semen quality in welders exposed to radiant heat. $B r J$ Ind Med.1992;49(1):5-10.

7. Kim KJ, Ahn HG. The effect of pore structure of zeolite on the adsorption of VOCs and their desorption properties by microwave heating. Microporous Mesoporous Mater. 2012;152:78-83.

8. Criteria for a Recommended Standard: Occupational Exposure to
Benzene.: NIOSH; 1974. Available from: http://www.cdc.gov/niosh/ docs/1970/74-137.html.

9. Xylene. NIOSH pocket guide to chemical hazards. Atlanta, GA: National Institute for Occupational Safety and Health, Centers for disease Control and Prevention.: NIOSH; 2005. Available from: http://www. cdc.gov/niosh/npg/npgdname.html.

10. Argo A, Bongiorno D, Bonifacio A, Pernice V, Liotta R, Indelicato $\mathrm{S}$, et al. A fatal case of a paint thinner ingestion: comparison between toxicological and histological findings. Am J Forensic Med Pathol.2010;31(2):186-91.

11. Wu JCS, Lin ZA, Tsai FM, Pan JW. Low-temperature complete oxidation of BTX on Pt/activated carbon catalysts. Catal Today. 2000;63(2-4):419-26.

12. Benmaamar Z, Bengueddach A. Correlation with different models for adsorption isotherms of M-xylene and toluene on zeolites. J Appl Sci Environ Sanit. 2007;2(2):43-56.

13. Off-Gas Treatment Technologies for Soil Vapor Extraction Systems: of the Practice.: Office of Superfund Remediation and Technology Innovation Office Solid Waste and Emergency Response U.S. Environmental Protection Agency; 2006. Available from: http://www. clu-in.org/download/remed/epa542r05028.pdf.

14. Liu H, Liu Y. Removal of p-xylene by a DBD-type plasma combined with catalyst. Environ Engin Manag J. 2011;10(6):749-53.

15. Ghasemi mobtaker H, Kazemian H, Molki negad A, Zeynali danaloo M, Pakzad M. Application of zeolite P and zeolite A synthesized from natural clinoptilolite for the removal of heavy metal cations Simulated wastewater.JChem Chem Eng. 2005;24(2):51-61.

16. Li Y, Täffner T, Bischoff M, Niemeyer B. Test Gas Generation from Pure Liquids: An Application-Oriented Overview of Methods in a Nutshell. Int J Chem Engin. 2012;2012.

17. Arthur F. Patty's Industrial Hygiene And Toxicology.Canada: WileyInterscience; 2000.

18. Rostami R, Jonidi Jafari A, Rezaee Kalantari R, Gholami M. Survey of modified Clinoptilolite Zeolite and Cooper Oxide nanoparticles-containing modified Clinoptilolite efficiency for polluted air BTX removal. Iran J Health Environ. 2012;5(1):1-8.

19. Nikolajsen K, Kiwi-Minsker L, Renken A. Structured Fixed-Bed Ad sorber Based on Zeolite/Sintered Metal Fibre for Low Concentration VOC Removal. Chem Engin Res Design. 2006;84(7):562-8.

20. Hong SS, Lee GH, Lee GD. Catalytic combustion of benzene over supported metal oxides catalysts. Korean J Chem Eng. 2003;20(3):440-4.

21. Gupta K, Rao N, Agarwal G. Adsorption of Xylene on Granular Activated Carbon in a Packed Bed. Int J Scie Tech Res. 2012;1(3):90-3.

22. Asilian H, Khavanin A, Afzali M, Dehestani S. Removal of Sty rene From Air by Natural and Modified Zeolite. Health Scope. 2012;1(1):7-11.

23. Impens NREN, van der Voort P, Vansant EF. Silylation of micro-, meso- and non-porous oxides: a review. Microporous Mesoporous Mater.1999;28(2):217-32.

24. Rahmani AR, Samadi MT, Ehsani HR. Investigation of clinoptilolite natural zeolite regeneration by air stripping followed by ion exchange for removal of ammonium from aqueous solutions. Iran J Environ Health Sci Engin. 2009;6(3):167-72. 